\title{
Comparison between monotherapy and combination therapy among inpatients with community-acquired pneumonia
}

\section{Perbandingan monoterapi versus terapi kombinasi pada pasien rawat inap dengan community acquired pneumonia}

\author{
Rike Syahniar*1, Muhammad Afif Akbar², Dayu Swasti Kharismaํ, Audia Nizhma Nabila³
}

\author{
${ }^{1}$ Departemen Mikrobiologi dan Parasitologi, Fakultas Kedokteran dan Kesehatan, Universitas \\ Muhammadiyah Jakarta \\ 2 Program Studi Profesi Dokter, Fakultas Kedokteran dan Kesehatan, Universitas Muhammadiyah Jakarta \\ 3 Departemen Farmakologi, Fakultas Kedokteran dan Kesehatan, Universitas Muhammadiyah Jakarta \\ *Corresponding author: rikesyahniar@gmail.com
}

\begin{abstract}
Background: Pneumonia causes high mortality rate, hospitalization cost, and cost of health services. There are some growing debates about the efficacy of different treatment management approaches. The use of certain antibiotic combination regimens and monotherapy have been associated with improved outcomes.

Objective: To identify the effectiveness of monotherapy and combination therapy on the length of stay

Methods: This retrospective study involved patients with community-acquired pneumonia who received empirical therapy between January and December 2017 at Jakarta Islamic Hospital of Cempaka Putih.

Results: Two hundred and ninety-four subjects were included in this study. The percentage of the subjects who received monotherapy and combination therapy was $73.8 \%$ and $26.2 \%$, respectively. The mean length of stay was 5 days. The most widely used antibiotic in this study was ceftriaxone with levofloxacin (35\%) for combination therapy and levofloxacin (38.2\%) for monotherapy. There was a relationship between comorbidities and long-term hospitalization $(p=0.008)$.

Conclusion: There was no significant difference between combination therapy and monotherapy in affecting the length of stay ( $\mathrm{p}=0.277)$.

Keywords: Pneumonia, monotherapy, combination therapy, Jakarta Islamic Hospital of Cempaka Putih

\section{Intisari}

Latar belakang: Pneumonia menyebabkan tingginya angka kematian, biaya rawat inap dan pelayanan kesehatan. Terdapat beberapa perdebatan yang berkembang mengenai efikasi pendekatan manajemen pengobatan yang berbeda. Penggunaan kombinasi rejimen antibiotik tertentu dan monoterapi telah dikaitkan dengan hasil yang lebih baik.

Tujuan: untuk menentukan efektivitas monoterapi dan terapi kombinasi terhadap lama rawat inap.

Metode: Penelitian retrospektif ini melibatkan pasien dengan community acquired pneumonia yang menerima terapi empiris antara Januari - Desember 2017 di Rumah Sakit Islam Jakarta (RSIJ) Cempaka Putih.

Hasil: Dua ratus sembilan puluh empat subjek dilibatkan dalam penelitian ini. Subyek yang menerima monoterapi dan terapi kombinasi sebesar $73,8 \%$ dan $26,2 \%$. Rerata lama rawat inap pada kelompok monoterapi dan dualterapi yaitu 5 hari. Antibiotik yang paling banyak digunakan dalam penelitian ini yaitu seftriakson dengan levofloksasin (35\%) untuk terapi kombinasi dan levofloksasin $(38,2 \%)$ untuk monoterapi. Terdapat hubungan antara komorbid dengan lama rawat inap $(p=0,008)$.
\end{abstract}


Kesimpulan: Tidak terdapat perbedaan bermakna antara terapi kombinasi dan monoterapi dengan lama rawat inap $(p=0,277)$

Kata kunci : Pneumonia, monoterapi, terapi kombinasi, RSIJ Cempaka Putih

\section{Pendahuluan}

Community Acquired Pneumonia (CAP) merupakan pneumonia yang diperoleh di luar rumah sakit atau yang didapat dari masyarakat. Pneumonia dapat disebabkan oleh bakteri, virus atau jamur (Irawan et al., 2019). Mikroorganisme penyebab CAP mencapai paru-paru melalui droplet dari bersin atau batuk sumber yang terinfeksi (misalnya virus pernapasan, C. pneumophila dan M. pneumoniae) atau sumber lingkungan (L. pneumophila), atau melalui aspirasi setelah kolonisasi nasofaring (S . pneumoniae, H. influenzae atau S. aureus) (Brown, 2012). Infeksi tersebut dapat bersifat serius, sering terjadi, disertai angka kesakitan dan kematian (Dewantara et al., 2017).

Insiden CAP pada pasien rawat jalan dan rawat inap rumah sakit diketahui 5-10 per 1000 pada populasi orang dewasa (Furlan et al., 2019). Pada tahun 2010, studi global mengenai beban penyakit melaporkan bahwa pneumonia yang termasuk dalam infeksi saluran pernapasan bawah merupakan penyebab kematian keempat di dunia dan menempatkan beban signifikan pada perawatan kesehatan (Lopardo et al., 2018; Lozano et al., 2012 ). Di Indonesia, pneumonia dikelompokkan kedalam 10 penyakit terbanyak penyebab rawat inap di rumah sakit. Berdasarkan data RISKESDAS, terjadi peningkatan prevalensi pneumonia berdasarkan diagnosis tenaga kesehatan (nakes) yaitu 1,6\% menjadi 2,0\% pada tahun 2013 hingga tahun 2018 (Kemenkes, 2018).

Pneumonia dapat melanda semua kelompok usia dan terjadi sepanjang tahun. Diagnosis terhadap pneumonia perlu ditegakkan dengan segera agar dapat diberikan tatalaksana yang sesuai. Antibiotik yang diberikan di awal bersifat empiris yaitu antibiotik diberikan atas dasar penyebab bakteri patogen terbanyak dan tersering penyebab pneumonia. Pasien dengan penyakit penyerta atau komorbid yang memiliki riwayat pemakaian antibiotik dalam 3 bulan sebelumnya menjadi dasar pemberian antibiotik empiris (Irawan et al., 2019; van der Poll \& Opal, 2009). Salah satu acuan yang dipakai oleh klinisi di Indonesia yaitu menurut Komunitas Penyakit Menular dari Amerika/American Thoracic Society (IDSA/ATS) mengenai terapi antibiotik yang dapat digunakan dalam tatalaksana pneumonia komunitas. Pemilihan antibiotik spektrum luas digunakan dengan harapan mampu melawan agen patogen penyebab pneumonia. Fluorokuinolon respirasi, atau $\beta$ laktam dan makrolida, atau $\beta$-laktam dan fluorokuinolon respirasi termasuk dalam beberapa pilihan antibiotik untuk pneumonia non ICU sesuai rekomendasi IDSA/ATS (Mandell et al., 2007).

Pemilihan antibiotik empiris pada pasien dengan pneumonia masih terbatas oleh adanya bukti (Liu et al., 2019). Pada pasien dengan rawat inap, monoterapi dengan ß-flurokuinolon 
respirasi mulai banyak digunakan, namun kombinasi dengan $\beta$-laktam dengan makrolida diketahui masih menunjukkan hasil yang baik. Studi yang dilaporkan oleh Rahmel et al. (2017) diketahui bahwa terapi kombinasi antibiotik meningkatkan kelangsungan hidup di antara pasien yang sakit kritis dengan penyakit infeksi akibat pneumokokus dibandingkan dengan mereka yang diobati dengan monoterapi $\beta$-laktam. Studi lain yang dilakukan oleh Metersky et al. (2007) menunjukkan penggunaan antibiotik kombinasi dengan makrolida dapat menurunkan risiko kejadian mortalitas dirumah sakit $(p=0,01)$, menurunkan kematian dalam 30 hari $(p=0,007)$, dan menurunkan kejadian rawat inap kembali dalam 30 hari $(p=0,004)$. Oleh karena itu, pemilihan antibiotik yang digunakan dapat mempengaruhi dampak yang akan menurunkan kejadian morbiditas dan mortalitas.

\section{Metode}

Penelitian ini merupakan penelitian secara retrospektif dengan mengumpulkan data rekam medis pasien mulai bulan Januari hingga Desember 2017 di RSIJ Cempaka Putih. Kriteria inklusi pada penelitian ini yaitu usia lebih dari 18 tahun dan pasien rawat inap yang didiagnosis CAP. Data karakteristik subyek disajikan secara deskriptif. Perbedaan rerata dua kelompok yaitu monoterapi dan terapi kombinasi terhadap lama rawat dan komorbid dilakukan uji statistik menggunakan Mann Whitney bila data tidak berdistribusi normal. Perbedaan bermakna didapatkan jika nilai $p<0,05$. Penelitian ini telah mendapat kelayakan etik oleh komisi etik Universitas Muhammadiyah Jakarta dengan no 276A/PE/KE/FKK/UMJ/XII/2018.

\section{Hasil dan pembahasan}

Sebanyak 294 data penderita pneumonia dari 1 Januari hingga 31 Desember 2017 yang memenuhi kriteria inklusi diikutsertakan pada studi ini. Mayoritas subjek dalam penelitian ini berusia kurang dari 60 tahun (72,8\%). Serupa dengan penelitian Lukitasari et al. (2019) melaporkan subyek penderita pneumonia komunitas sebagian besar berusia kurang dari 60 tahun $(56,7 \%)$. Jenis kelamin yang paling banyak pada penelitian ini adalah laki-laki $(51,7 \%)$. Studi lain oleh Faisal et al. (2014), menyebutkan jenis kelamin terbanyak yaitu laki-laki $(74,5 \%)$. Penelitian lain oleh E. F. Sari et al. (2016) melaporkan jenis kelamin laki-laki yang terbanyak yaitu $(67,6 \%)$. Hal ini menunjukkan laki-laki lebih sering menderita infeksi saluran pernafasan

Hasil nilai leukosit dari sebagian besar subyek meningkat baik secara keseluruhan $(63,6 \%)$ maupun pada kelompok monoterapi $(63,1 \%)$ dan terapi kombinasi $(64,9 \%)$. Nilai leukosit pada pneumonia yang disebabkan oleh bakteri yaitu antara 15,000 sampai $40,000 / \mathrm{mm}^{3}$ dengan predominan sel polimorfonuklear (Wardah et al., 2013). Pada pasien pneumonia karena infeksi bakteri daripada virus cenderung mempunyai nilai leukosit $>15,000 / \mathrm{mm}^{3}$. Hasil tersebut dapat dipengaruhi pula oleh stadium penyakit (E. F. Sari et al., 2016). Penelitian lain oleh 
Subanada \& Purniti (2010) mendapatkan kadar leukosit $>15,0 \times 10^{9}$ /L lebih banyak pada penyebab bakteri (72\%) dibanding penyebab non-bakteri (38\%). Leukosit merupakan sistem imunitas yang bersifat tidak spesifik, sehingga infeksi yang terjadi di tempat lain selain paru dapat memberikan gambaran leukositosis.

Sebanyak 217 (73,8\%) menerima monoterapi dan 77 (32,5\%) menerima terapi kombinasi. Hasil ini serupa dengan Lukitasari et al. (2019) memperoleh 58\% monoterapi dan $42 \%$ dual terapi pemberian antibiotik pada pneumonia komunitas. Studi oleh Sajinadiyasa et al. (2011) mendapatkan hasil berbeda yaitu 55 orang (73,30\%) dan 20 orang (26,70\%) menerima antibiotik dual terapi dan monoterapi. Antibiotik yang paling banyak digunakan dalam penelitian ini yaitu golongan fluorokuinolon. Pilihan antibiotik yang disarankan pada pasien dewasa untuk pneumonia komunitas yaitu golongan makrolida atau doksisiklin atau fluorokuinolon terbaru. Menurut panduan IDSA/ATS tahun 2019 untuk monoterapi dengan komorbid direkomendasikan menggunakan fluorokuinolon respirasi seperti levofloksasin atau moksifloksasin atau gemifloksasin. Pada penelitian ini terapi kombinasi terdiri dari pemberian dua maupun tiga antibiotik. Tujuan terapi kombinasi adalah meningkatkan aktivitas antibiotik terhadap infeksi spesifik, mengurangi dan memperlambat risiko timbulnya bakteri yang resisten. Selain itu, adanya penyakit penyerta infeksi lainnya (komorbid) pada penelitian ini, maka pemberian antibiotik kombinasi ini memang diperlukan. Antibiotik spektrum luas dapat digunakan secara empiris sampai adanya hasil kultur. Setelah bakteri patogen diketahui, pemberian antibiotik menggunakan antibiotik spektrum sempit sesuai dengan patogen yang teridentifikasi. Streptococcus pneumoniae merupakan bakteri penyebab paling umum hingga 50\% dari kasus CAP. Salah satu keuntungan kombinasi terapi yaitu pada S. pneumonia yang resisten terhadap antibiotik golongan $\beta$-laktam. Penggunaan kombinasi antibiotik golongan lain dapat meningkatkan efektifitas pada bakteri yang resisten terhadap $\beta$-laktam. 
60 | Rike, S. /Jurnal Ilmiah Farmasi (Scientific Journal of Pharmacy) 17(1) Januari-Juli 2021, 56-63

Tabel 1. Karakteristik subyek penelitian

\begin{tabular}{lccc}
\hline \multicolumn{1}{c}{ Karakteristik } & \multicolumn{2}{c}{ Terapi } & Total (\%) \\
\cline { 2 - 3 } & $\begin{array}{c}\text { Monoterapi } \\
\mathbf{n = 2 1 7}(\mathbf{7 3 , 8 \% )}\end{array}$ & $\begin{array}{c}\text { Terapi kombinasi } \\
\mathbf{n = 7 7}(\mathbf{2 6 , 2 \% )}\end{array}$ & $\mathbf{n = 2 9 4}$ \\
\hline Usia & $193(88,9)$ & $21(27,3)$ & $214(72,8)$ \\
$\begin{array}{l}\text { 18-59 tahun } \\
\geq 60 \text { tahun }\end{array}$ & $24(11,1)$ & $56(72,7)$ & $80(27,2)$ \\
Jenis Kelamin & $106(48,8)$ & $46(59,7)$ & $152(51,7)$ \\
Laki-laki & $111(51,2)$ & $31(40,3)$ & $142(48,3)$ \\
Perempuan & $5(2,3)$ & $8(10,4)$ & $13(4,4)$ \\
Nilai Leukosit & $75(34,6)$ & $19(24,7)$ & $94(32)$ \\
Rendah $(<4.500)$ & $137(63,1)$ & $50(64,9)$ & $187(63,6)$ \\
Normal $(4.500-10.000)$ & $197(90,8)$ & $71(92,2)$ & $268(91,2)$ \\
Meningkat $(>10.000)$ & $20(9,2)$ & $6(7,8)$ & $26(8,8)$ \\
Komorbid & & & \\
Ada & & & \\
Tidak ada & & & \\
\hline
\end{tabular}

Rerata lama rawat inap antara monoterapi dan terapi kombinasi pada penelitian ini yaitu 5 hari. Setelah dilakukan analisis, tidak terdapat perbedaan antara lama rawat pada kelompok monoterapi dan terapi kombinasi ( $p=0,277)$. Rerata ini sama dengan Lukitasari et al. (2019) yaitu penggunaan antibiotik setelah 5 hari menunjukkan perbaikan rerata frekuensi napas yang termasuk salah satu dari penilaian perbaikan klinis. Hasil lain berbeda dengan Sajinadiyasa et al. (2011), rerata lama rawat pada kelompok monoterapi dan dual terapi yaitu 14 hari dan 8 hari. Namun, studi Sajinadiyasa et al. (2011) memiliki kesamaan yaitu tidak terdapat perbedaan yang bermakna antara lama rawat pada kelompok monoterapi dan terapi kombinasi $(p=0,075)$ Pada pasien dengan komorbid yang berat dan usia lanjut dapat mempengaruhi lama rawat pasien tersebut.

Tabel 2. Perbandingan antara pemberian antibiotik dengan lama rawat inap pada pasien pneumonia komunitas

\begin{tabular}{cccc}
\hline $\begin{array}{c}\text { Variabel } \\
(\boldsymbol{p} \text {-value) }\end{array}$ & $\begin{array}{c}\text { Monoterapi } \\
\text { (mean } \pm \text { SD) }\end{array}$ & $\begin{array}{c}\text { Terapi kombinasi } \\
\text { (mean } \pm \text { SD) }\end{array}$ & $\begin{array}{c}\text { Komorbid } \\
\text { (mean } \pm \text { SD) }\end{array}$ \\
\hline Lama Rawat & & $5,19 \pm 3,77$ & $5,6 \pm 3,8$ \\
0,277 & $5,74 \pm 3,78$ & & \\
0,008 & & & \\
\hline
\end{tabular}

Komorbid terbanyak pada penelitian ini yaitu TB Paru (15,3\%) dan Congestive Heart Failure (CHF) (15\%). Hasil uji Mann Whitney menunjukkan bahwa komorbid mempengaruhi lama rawat inap $(p=0,008)$. Studi oleh Chang et al. (2016) memperoleh pneumonia dengan TB memiliki HR 2,39 (95\% CI = 2,03-2,82) dibandingkan dengan komorbid lainnya. Hal tersebut disebabkan bakteri lain lebih mudah untuk menginfeksi pada kondisi paru yang sudah pernah terinfeksi TB sehingga menyebabkan peradangan paru-paru. Menurut M. A. Sari et al. (2018), mendapatkan 
komorbid terbanyak yaitu PPOK (22,6\%) sedangkan studi oleh Nguyen et al. (2019) memperoleh penyakit jantung iskemik sebagai komorbid terbanyak $(24,5 \%)$. Komorbid merupakan faktor penting yang berperan pada prognosis dan risiko terjadinya pneumonia. Fungsi saluran pernafasan dapat dipengaruhi oleh penyakit serebrovaskular dan gagal jantung kongestif. Hal ini juga dapat mempengaruhi gangguan bersihan mukosiliar, refleks batuk, dan batuk menjadi tidak efektif.

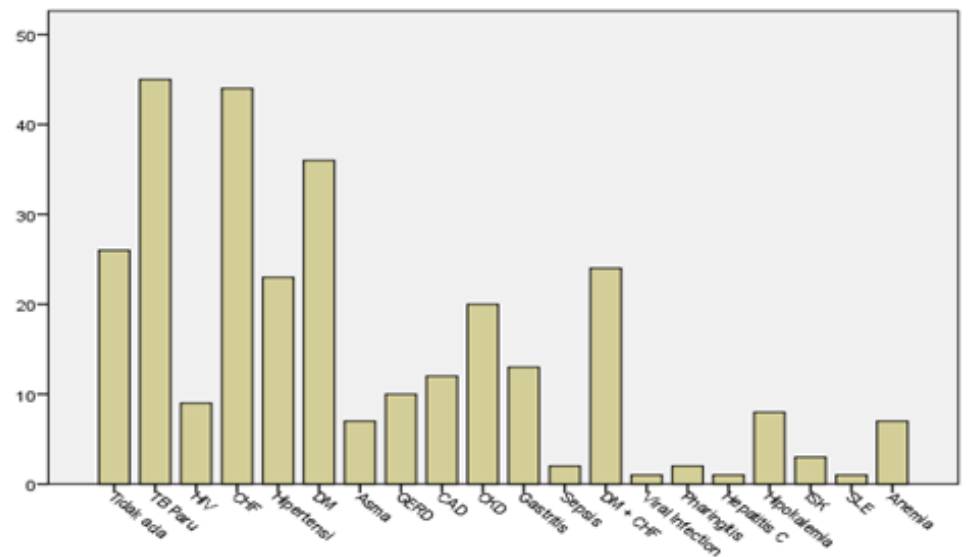

Gambar 1. Karakteristik komorbid pada pasien pneumonia komunitas di RSIJ Cempaka Putih tahun 2017

\section{Kesimpulan}

Dari hasil penelitian diketahui penggunaan monoterapi lebih banyak digunakan, meskipun tidak terdapat perbedaan bermakna antara monoterapi dengan terapi kombinasi terhadap lama rawat. Monoterapi yang dipilih sebagian besar yaitu golongan flurokuinon, sedangkan untuk terapi kombinasi digunakan $\beta$-laktam dan fluorokuinolon. Hasil analisis komorbid dengan lama rawat diketahui terdapat perbedaan antara komorbid dengan ataupun tanpa komorbid terhadap lama rawat.

Pada penelitian ini terdapat beberapa keterbatasan karena data diambil secara retrospektif dan kurangnya variabel seperti hasil kultur. Oleh karena itu diperlukan penelitian lebih lanjut dengan metodologi yang lebih baik, sehingga dapat lebih banyak mengevaluasi faktor-faktor lain yang mempengaruhi outcome pasien dengan $C A P$.

\section{Ucapan terimakasih}

Penulis mengucapkan terima kasih kepada Fakultas Kedokteran dan Kesehatan Universitas Muhammadiyah Jakarta dan RSIJ Cempaka Putih atas izin yang diberikan sehingga penulis dapat memperoleh data penelitian. 


\section{Daftar pustaka}

Brown, J. S. (2012). Community-acquired Pneumonia. Clinical Medicine, 12(6), 538-543. doi:https://dx.doi.org/10.7861\%2Fclinmedicine.12-6-538

Chang, T.-M., Mou, C.-H., Shen, T.-C., Yang, C.-L., Yang, M.-H., Wu, F.-Y., \& Sung, F.-C. (2016). Retrospective cohort evaluation on risk of pneumonia in patients with pulmonary tuberculosis. Medicine, 95(26), 1-6. doi:10.1097/MD.0000000000004000

Dewantara, A., Suradi, S., Reviono, R., Rima, A., Harsini, H., \& Aphridasari, J. (2017). Pengaruh Pemberian Zink Selama 5 Hari terhadap Kadar Endothelin-1, Tumor Necrosis Factor- $\alpha$ dan Perbaikan Klinis Penderita. Jurnal Respirologi Indonesia, 37(1), 8-14.

Faisal, F., Burhan, E., Aniwidyaningsih, W., \& Kekalih, A. (2014). Penilaian Respons Pengobatan Empiris pada Pasien Rawat Inap dengan Pneumonia Komunitas Journal Respirology, 34(2), 60-70.

Furlan, L., Erba, L., Trombetta, L., Sacco, R., Colombo, G., Casazza, G., Costantino, G. (2019). Shortvs Long-course Antibiotic Therapy for Pneumonia: a Comparison of Systematic Reviews and Guidelines for the SIMI Choosing Wisely Campaign. Internal and emergency medicine, 14(3), 377-394. doi:10.1007/s11739-018-1955-2

Irawan, R., Reviono, R., \& Harsini, H. (2019). Korelasi Kadar Copeptin dan Skor PSI dengan Waktu Terapi Sulih Antibiotik Intravena ke Oral dan Lama Rawat Pneumonia Komunitas. Jurnal Respirologi Indonesia, 39(1), 44-53.

Kemenkes, R. (2018). Hasil Utama Riset Kesehatan Dasar 2018. In. Jakarta: Badan Penelitian dan Pengembangan Kesehatan.

Liu, S., Tong, X., Ma, Y., Wang, D., Huang, J., Zhang, L., Fan, H. (2019). Respiratory Fluoroquinolones Monotherapy vs. $\beta$-Lactams With or Without Macrolides for Hospitalized CommunityAcquired Pneumonia Patients: A Meta-Analysis. Frontiers in Pharmacology, 10, 489. doi:10.3389/fphar.2019.00489

Lopardo, G. D., Fridman, D., Raimondo, E., Albornoz, H., Lopardo, A., Bagnulo, H., Stamboulian, D. ( 2018). Incidence Rate of Community-acquired Pneumonia in Adults: A Population-based Prospective Active Surveillance Study in Three Cities in South America. BMJ Open,, 8(4), 19. doi:https://doi.org/10.1136/bmjopen-2017-019439

Lozano, R., Naghavi, M., Foreman, K., Lim, S., Shibuya, K., Aboyans, V., A., M. Z. (2012 ). Global and Regional Mortality from 235 Causes of Death for 20 Age Groups in 1990 and 2010: A Systematic Analysis for the Global Burden of Disease Study 2010. The Lancet, 380(9859), 2095-2128. doi:10.1016/s0140-6736(12)61728-0

Lukitasari, N., Radji, M., \& Rianti, A. (2019). Analisis Perbandingan antara Monoterapi dengan Dualterapi Antibiotik Extended Empiric pada Pasien Community-Acquired Pneumonia di RSUP Fatmawati Jakarta. Jurnal Sains Farmasi \& Klinis, 6(2), 147-157. doi:10.25077/jsfk.6.2.147-157.2019

Mandell, L. A., Wunderink, R. G., Anzueto, A., Bartlett, J. G., Campbell, G. D., Dean, N. C., Whitney, C. G. (2007). Infectious Diseases Society of America/American Thoracic Society Consensus Guidelines on the Management of Community-acquired Pneumonia in Adults. Clinical Infectious Diseases, 44, S27-S72. doi:10.1086/511159

Metersky, M. L., Ma, A., Houck, P. M., \& Bratzler, D. W. (2007). Antibiotics for Bacteremic Pneumonia: Improved Outcomes with Macrolides but not Fluoroquinolones. Chest, 131(2), 466-473. doi:10.1378/chest.06-1426

Nguyen, M. T. N., Saito, N., \& Wagatsuma, Y. (2019). The Effect of Comorbidities for the Prognosis of Community-acquired Pneumonia: an Epidemiologic Study Using a Hospital Surveillance in Japan. BMC Research Notes, 12(1), 817. doi:10.1186/s13104-019-4848-1

Rahmel, T., Asmussen, S., Karlik, J., Steinmann, J., Adamzik, M., \& Peters, J. (2017). Moxifloxacin Monotherapy Versus Combination Therapy in Patients with Severe Community-acquired Pneumonia Evoked ARDS. BMC Anesthesiology, 17(1), 1-9. doi:10.1186/s12871-0170376-5 
Sajinadiyasa, I. G., Rai, I. N., \& Sriyeni, L. (2011). Perbandingan antara Pemberian Antibiotika Monoterapi dengan Dualterapi terhadap Outcome pada Pasien Community Acquired Pneumonia (CAP) di Rumah Sakit Sanglah Denpasar. Jurnal Penyakit Dalam, 12(1), 13-20.

Sari, E. F., Rumende, C. M., \& Harimurti, K. (2016). Faktor-Faktor yang Berhubungan dengan Diagnosis Pneumonia pada Pasien Usia Lanjut. Jurnal Penyakit Dalam Indonesia, 3(4), 183192. doi:http://dx.doi.org/10.7454/jpdi.v3i4.51

Sari, M. A., Raveinal, R., \& Noverial, N. (2018). Derajat Keparahan Pneumonia Komunitas pada Geriatri Berdasarkan Skor CURB-65 di Bangsal Penyakit Dalam RS. Dr. M. Djamil Padang Tahun 2016. Jurnal Kesehatan Andalas, 7(1), 102-107. doi:https://doi.org/10.25077/jka.v7i1.786

Subanada, I. B., \& Purniti, N. P. S. (2010). Faktor-Faktor yang Berhubungan dengan Pneumonia $\begin{array}{llll}\text { Bakteri pada Anak. Sari Pediatri, 12(3), } & \text { 184-189. }\end{array}$ doi:https://dx.doi.org/10.14238/sp12.3.2010.184-9

van der Poll, T., \& Opal, S. M. (2009). Pathogenesis, Treatment, and Prevention of Pneumococcal Pneumonia. The Lancet, 374(9700), 1543-1556. doi:10.1016/s0140-6736(09)61114-4

Wardah, W., Nurjannah, N., Bakhtiar, B., \& Daulay, R. S. (2013). Penanda Infeksi Bakteri pada Pneumonia Anak. Majalah Kedokteran Nusantara: The Journal of Medical School, USU, 46(2), 107-111. 